\title{
REFLEXÕES PANDÊMICAS
}

Mariane Amanda de Oliveira

DOI: http://dx.doi.org/10.18616/intcov41

No pequeno apartamento existem três janelas

Não eram as mais antigas, bonitas ou valiosas

Porém, quando o morador solitário encontrou-se confinado e em práticas ociosas,

As pequenas janelas passaram a refletir as tonalidades mais belas

A primeira tonalidade era a solidão

O morador solitário não parecia dar-se conta dela

Sabendo sobre o mundo por meio de uma ou outra espiadela

Não saberia dizer se esse tom sempre esteve ali ou não

Outra interessante tonalidade era a liberdade

Essa parecia confundir-se com os tons de azul nas janelas

Todas aqueles azuis como em diferentes telas

Fê-lo pensar se tratou seu azul com sinceridade em toda a sua verdade

Uma constante tonalidade era a saudade

O morador solitário aprendeu a sempre conviver com ela

As inúmeras tonalidades refletidas nas janelas 
Fizeram com que o morador indagasse: conheci a ti mundo, antes delas?

Elas discretas e singelas gritavam: efêmera é tua estada! Não te esqueças dela!

O morador colorido pela intensidade das cores provindas delas respondeu: quando não mais precisar olhar tonalidades pela janela, prometo dedicar-me a minha jornada curta e bela. 